\title{
KANT ON THE “CONDITIONS OF THE POSSIBILITY” OF EXPERIENCE
}

\author{
Claude Piché, Université de Montréal
}

[ This is a preprint. Do not quote. The final revised version appeared in : H. Kim and S. Hoeltzel (eds), Transcendental Inquiry. Its History, Methods and Critiques, Cham (Switzerland), Palgrave Macmillan, 2016, p. 1-20. ]

[ Pour la traduction française de ce texte, voir ci-dessous. ]

\begin{abstract}
The aim of this paper is to set out some features of Kant's conception of transcendental philosophy. I would like to argue that this philosophy, although it is situated at a higher level of discourse than common knowledge, does not essentially transcend the limits that it sets to this knowledge. In order to achieve this, I stress the fact that Kant regards experience as a mere "possibility." Now, the Critique of Pure Reason explains that the human understanding cannot conceive of an absolute possibility, but only a relative one, namely a possibility that is tied to conditions. And possible experience as a whole is no exception here. Hence the expression "conditions of the possibility of experience" which designates the topic of the Transcendental Analytic. This also means that experience is "contingent" (A 737/B 765). It is not in itself necessary; rather, it is dependent upon certain conditions. But then we learn that the most important transcendental conditions for this experience, i.e., the dynamic principles, are themselves "contingent" (A 160/B 199). Consequently, these transcendental conditions are not unconditioned; they in turn depend on empirical conditions, over which they have no control.
\end{abstract}

Keywords: transcendental philosophy, experience, absolute possibility, contingency, conditions

In what follows, I would like to bring out some features of Kant's conception of transcendental philosophy in the Critique of Pure Reason. One of the aims of this work was to answer the question raised in the famous letter to Markus Herz of February $21^{\text {st }}, 1772$, about the possibility of a priori knowledge's relating to its object. ${ }^{1}$ And as we know, the answer elaborated in the Critique restricts the use of this pure knowledge to possible experience. Knowledge $a$ priori is valid only when applied to appearances, within experience. It is therefore a finite knowledge, limited to the phenomenal world. 
Now the question is: What is the legitimacy of Kant's own transcendental discourse when we take account of the restrictions imposed on human knowledge as a result of this very investigation? In other words, the use of $a$ priori knowledge being restricted to possible experience, how could the knowledge claim of this philosophical enquiry be justified if it does not itself take place within possible experience? The problem already becomes obvious with the formulation of the main result of the critical investigation, namely that the only valid sphere for $a$ priori knowledge is "possible experience." Yet how are we to understand the use of the word "possible" here? To be sure, possibility is a modal category whose conditions of legitimate application are strictly determined and restricted in the transcendental Analytic. And the same goes for the category of contingency, which, as we will see, plays an important role in specifying the status of the conditions of the possibility of experience. But then again the question is: Does Kant make an inappropriate or illegitimate use of these categories when, rather than applying them to objects of a possible experience, he uses them to describe the scope of valid a priori knowledge as a whole? By apparently removing the restrictions on their use here, it seems as though Kant is making a transcendent or, as he would say, "transcendental," employment of the categories of modality.

I will argue, however, that this use of the categories complies, all things considered, with the constraints imposed upon them for their application in experience. We will find that the categories at work in Kant's transcendental discourse are not employed without caution in their purely intellectual significance, which would lead them to open unto the unconditioned, as in the Transcendental Dialectic. On the contrary, the standpoint from which critical philosophy condemns every attempt to gain knowledge of the unconditioned is not itself unconditioned. I would like to show that transcendental philosophy, even when it circumscribes the limits of human knowledge with the help of the modal categories of possibility and contingency, nevertheless remains finite and refrains from overstepping the "bounds of sense." In order to achieve this, we will have to pay attention and define carefully Kantian expressions found in the first Critique such as "possible experience," "transcendental knowledge," "conditions of the possibility," and "contingency" which in the end will lead us to establish the modal status of the ultimate presuppositions of critical philosophy. 


\section{Possible experience}

Before we inquire into the role played by possible experience in the transcendental philosophy developed in the first Critique, we would be well advised to focus on the meaning of each of these words. "Experience" is a well-known Kantian term designating the knowledge of objects that are "given in empirical intuition" or, if one prefers, the "knowledge of the objects through perception." The short definition is thus "empirical knowledge,"2 whereby it is understood that this knowledge lays claim to objectivity. Experience is in fact objective empirical knowledge.

"Possibility" is a modal category which, from a strictly logical point of view, refers to that which does not contradict itself. To say that a concept is "possible" simply means that its internal components are not in contradiction with each other. This is what Baumgarten in his Metaphysica calls "absolute" possibility ${ }^{3}$ - a characterization for which he is criticized in Kant's lectures on metaphysics as well as (though implicitly) in the Transcendental Dialectic. ${ }^{4}$ In fact, Baumgarten uses the adjective "absolute" to designate "intrinsic" possibility, which according to Kant is the "least" that can be said of the concept of an object. But the strong meaning of the word should be maintained. In Kant's view, absolute possibility properly signifies the "most" that can be said of a concept, namely that its object is possible literally "in all respects" and "without any restriction" whatsoever. ${ }^{5}$

Kant feels the need to restore the strong sense of the term "absolute" at the beginning of the Transcendental Dialectic because it is synonymous with "unconditioned," which is the main topic of this second part of the Critique devoted to the logic of illusion. Indeed, a possibility that is absolute in the full sense of the word pertains not to the understanding but to reason, ${ }^{6}$ and this category gives rise to the same problem as the modal concept of "unconditioned necessity" used by the dogmatic metaphysician in the cosmological proof of the existence of God. That is, both concepts exceed the grasp of the human mind: "The unconditioned necessity, which we need so indispensably as the ultimate sustainer of all things, is for human reason the true abyss."7 The treatment reserved for the modal categories in the Transcendental Analytic reveals that only "hypothetical" necessity, that is, conditioned necessity, is available to human cognition, and the same goes for possibility, as we learn in Reflexion 4005: "With reason we can cognize only conditioned possibility." 8 The only kind of possibility that can be grasped by a finite unederstanding is relative possibility, namely that which is possible only in some respects. 
Accordingly, possibility is cognizable only if it is "restricted to conditions." " Let us take for instance Kant's example of the "invented concepts" of substances and forces supposedly present in experience. It is not enough to say that such concepts are possible because they are not selfcontradictory. To be sure, this satisfies the minimal requirement of their logical possibility, but their real possibility also has to be established within experience by showing that these objects can be instantiated according to its known laws. ${ }^{10}$ This is a clear example of conditioned possibility.

Now when Kant considers possible experience as a whole, rather than just particular objects within it, he maintains a similar restriction on his recourse to the concept of possibility. Experience might well be declared "possible," but here again only as a conditioned possibility. Hence the central expression for the Critique of Pure Reason: "conditions of the possibility of experience." ${ }^{\prime 11}$ Experience taken globally will thus be possible solely under a set of conditions. As we can see, Kant remains coherent in his use of the category of possibility: experience's possibility also depends on conditions, and most importantly on transcendental conditions. We will have to enquire into the nature of this transcendental conditioning, but before going any further we must again focus our attention on Kant's terminology.

\section{Transcendental knowledge}

Let us quote the canonical definition of the term "transcendental" given in the second edition of the Introduction of the Critique: "I call transcendental all knowledge that is occupied not so much with objects but rather with our mode of knowledge of objects insofar as this mode of knowledge is to be possible a priori." ${ }^{12}$ Here we clearly have two levels of knowledge: a first level concerned with the knowledge of objects and a second level dealing with our mode of knowledge a priori of these objects, which is precisely what transcendental knowledge is about. This means that in the Transcendental Analytic Kant is concerned primarily with a priori knowledge, or better: with our a priori mode of knowledge of objects.

However, all a priori knowledge is subject to a constraint: it can never reach the object in its actuality. For this, according to the teachings of the transcendental Analytic, the empirical dimension of the object must be added, at which point the knowledge becomes a posteriori. As we can read in the Metaphysical Foundations of Natural Science, "[ $\mathrm{t}$ ] $\mathrm{know}$ something a priori means to know it in its mere possibility." "13 Transcendental knowledge is no exception here, and 
so it is no surprise that it is oriented exclusively toward "possible" experience. ${ }^{14}$ The a priori knowledge introduced in the Transcendental Analytic is aimed at grounding the mere possibility of experience, and for this purpose it has to "abstract from everything empirical in the appearances." 15

Furthermore, it must be noted that knowledge of the a priori conditions of experience is not just any kind of a priori knowledge. It is, as I already said, a second-level knowledge. Its distinctive nature will become clear if we compare it with first-level kind of a priori knowledge such as pure geometry. While geometry is focused exclusively on its objects, which are merely ideal, the a priori conditions of experience on the other hand concern our mode of knowledge of real objects insofar as it presents their a priori components. It is nonetheless a form of 'knowledge', with its own truth claim - not empirical, to be sure, but transcendental. And since, for Kant, truth means adaequatio, that is, the correspondence of knowledge with its correlate, ${ }^{16}$ transcendental truth also involves such a correlate: possible experience.

In order to establish this correlation we can mention the two passages in the Analytic dealing with this specific truth claim. The first one appears, as we know, in the Schematism chapter: “...transcendental truth, which precedes all empirical truth and makes it possible, consists in the general relation to this [the entirety of all possible experience, C.P.]." ${ }^{\prime 17}$ The schemata are those products of the imagination that allow the pure concepts of the understanding to connect with possible experience. These a priori concepts thereby acquire their truth, that is, their objective validity, since from then on they have a correlate that can ground their claim to transcendental truth. The second passage is to be found in the Postulates of Empirical Thinking, to which we will come back later on. It concerns the categories of relation, which gain their objective validity by their mere reference to experience in general: "...one cognize[s] their objective reality [of the categories of relation, C.P.], i.e., their transcendental truth, and, to be sure, independently of experience, but yet not independently of all relation to the form of an experience in general..." ${ }^{\prime 18}$ On the one hand, the transcendental principles laid out in the Analytic acquire their truth through their relation to possible experience; on the other hand, experience owes its own possibility to these a priori conditions. 'Possible experience' thus has a twofold meaning: 1) experience is made possible by a priori conditions; and 2) possible experience confers validity on the entire transcendental apparatus. ${ }^{19}$ 
This correlation is difficult to grasp since it takes place at a virtual level; it has no anchorage point, so to speak. If the correlate of the a priori conditions of experience were a given object to which such knowledge could correspond, the reader of the Critique of Pure Reason would have a much easier task. But as we have seen, this correlate is a mere possibility. There is no actual object nor any well secured knowledge to rely on. It goes without saying that Kant is fully aware of this situation, which is bound up with his way of proceeding in the Critique, as he will himself later admit in the Prolegomena. The Critique does not presuppose any "fact" whatsoever. ${ }^{20}$ The only thing that is given is reason as a faculty of cognition, which contains (together with the pure forms of intuition) the a priori elements that make all knowledge, and indeed all objects of knowledge, possible. Beginning with those a priori elements, the first Critique adopts a synthetic and progressive procedure that leads to the possibility of experience. In contrast, the Prolegomena of 1783 offer a more accessible presentation of transcendental philosophy beginning from two sciences, pure mathematics and pure natural science, both of which are already firmly established and aptly combined in Newtonian physics. A regressive analysis - from the given to its presuppositions -- of these pure sciences thus allows a much easier access to their a priori conditions of possibility.

As a reminder, we may quote a passage from the Transcendental Methodology which highlights the difficulty of proving a transcendental principle when the regressive procedure is excluded, as it is the case in the first Critique. What I have in mind is the end of the chapter on the Discipline of Pure Reason in Dogmatic Use, where Kant writes that the principle of causality can be proven apodictically, but only with regard to the experience that is thereby made possible. The proof therefore cannot take experience for granted and rely on it as a point of reference, since experience is first made possible by this very principle: "it [the principle of causality] has the special property that it first makes possible its ground of proof, namely experience, and must always be presupposed in this [experience]. ${ }^{, 21}$

\section{The a priori conditions of possible experience}

Among the conditions of experience, Kant distinguishes the conditions of the possibility of experience from the conditions of its actuality. The first are a priori and manifestly receive the most attention in the Critique since they are specifically transcendental, while the others are $a$ posteriori, that is, empirical. To be sure, together they constitute what makes experience 
'possible', yet, in the narrow sense, it is the a priori conditions that are especially concerned with the "possibility" of experience.

The entire set of conditions for experience, namely the conditions of the possibility, of the actuality and of the necessity of an appearance, are laid out systematically in the three Postulates of Empirical Thinking in General:

1- Whatever agrees with the formal conditions of experience (in accordance with intuition and concepts) is possible.

2- That which is connected with the material conditions of experience (of sensation) is actual.

3- That whose connection with the actual is determined in accordance with the general conditions of experience is (exists) necessarily. ${ }^{22}$

As we can see, the first postulate concerns the formal aspect of experience, the second its matter, i.e., "sensation" which is for Kant "the sole characteristic of actuality," 23 whereas the third, which deals with an "existence" that is at the same time recognized as necessary, is simply a combination of the first two Postulates. ${ }^{24}$ In this third case we can think of Kant's famous example, "the sun warms the stone." The actuality of the warmth of the stone (known through sensation) is necessary because it is the effect of the sun's rays.

To be sure, the first Postulate has to do with the conditions that make an "object" (Ding, Gegenstand $)^{25}$ possible, but since the transcendental deduction shows that experience and its objects share the same conditions of possibility, ${ }^{26}$ the "formal" conditions in the first Postulate are clearly the a priori conditions of possible experience in general. In other words, while the second Postulate deals with the empirical conditions of experience, the first introduces its transcendental conditions, namely the pure forms of intuition and the pure concepts of the understanding. These a priori elements are the starting-point of the Deduction, which endeavors to demonstrate the validity of these a priori formal conditions. ${ }^{27}$ It goes without saying that these intuitive and conceptual elements are combined in the eight principles presented in the Transcendental Analytic. The principles show the interaction of these elements that, as a priori synthetic propositions, embody the formal conditions of the possibility of experience. Let us note that experience does not have to be actual at this stage since these transcendental propositions acquire their objective validity simply by making experience possible. 
Now in order to illustrate the finite character of Kant's transcendental philosophy, we must consider more closely the nature of these transcendental conditions of experience. As we know Kant divides his table of the principles of the understanding under two headings: mathematical and dynamical. Of these two classes, it is the dynamical principles that are the most relevant to my purpose here, but their special status can best be explained by first establishing a contrast with the mathematical principles, namely the Axioms of Intuition and the Anticipations of Perception. Obviously, these principles do not themselves belong to mathematics, yet they deserve this name insofar as they authorize the full application of the results of mathematics to experience. The reason for this is simple, but it might nevertheless be reminded: the synthesis of apprehension of the manifold in experience is, according to the Axioms of Intuition, the "same synthesis" 28 as the one at work in the quantitative synthesis of the homogenous units of pure intuition in mathematics. This means that all the operations of quantification made a priori in arithmetic and in Euclidian geometry are automatically and universally applicable to experience so that their objective validity is guaranteed from the start. It thus comes as no surprise when Kant argues that these principles are "constitutive" of the objects of experience as far as their intuition is concerned. The quantification of extensive as well as of intensive magnitudes can be fully anticipated; for example, everything that geometry says about space as a formal intuition is by the same token valid for concrete experience. This is also what Kant has in mind when, speaking of intensive magnitude, he writes that the luminosity of the sun can be calculated $a$ priori. To be sure, the sun and its light are not known a priori, but the calculus as such allows one to "construct" this magnitude "a priori.",29

It is obvious that all the principles of the Transcendental Analytic are 'necessary' conditions of the possibility of experience, but the mathematical principles are further declared "necessary" in their very exercise (Ausübung): their evidence is intuitive and they are a priori constitutive of the object of experience itself, at least as far as its anticipated magnitude is concerned. ${ }^{30}$ On the other hand, the application of the dynamical principles, that is, the Analogies of Experience and the Postulates of Empirical Thinking in General, are said to be merely "contingent" in the sense that even though these principles anticipate experience, their exercise is "indirect" and "mediated." 31 The reason for this distinction is that the latter principles are concerned not so much with the mere intuition of the object as with its existence. And existence 
cannot be constructed a priori; it must first manifest itself empirically in order to be regulated by the dynamical principles.

Consider the dynamical principle of causality. According to this principle, once an appearance has presented itself through a sensation (for instance, a stone that becomes warm), this event can only be interpreted as an effect whose cause must be sought in a preceding moment in time, such as the emission of sunrays, for example. The difference between mathematical and dynamical principles can best be illustrated by Kant's distinction between mathematical and

philosophical (dynamical) types of "analogy." 32 A mathematical analogy deals solely with quantitative relations, so that if three terms of an equation are given then the fourth can be found a priori and determined with precision. In contrast, a dynamical analogy concerns the qualitative (typically causal) relations between objects with respect to their existence. First, the fourth term is "given" (for example, the warm stone), and then the principle only provides a rule to inquire about the third term, without allowing us to anticipate a priori what this third element will be. ${ }^{33}$ This givenness of the event which escapes the control of the knowing subject is what leads Kant to claim that the exercise of these dynamic principles is merely "contingent": "The a priori conditions ... of the existence of the objects of a possible empirical intuition are in themselves only contingent." 34 This comes somewhat as a surprise because it seems to weaken the status of the dynamical principles, which are central for the possibility of experience. Not only is the principle of causality the one that reoccurs most of the time when Kant seeks to illustrate the role of the transcendental principles, but we also know, thanks to Paul Guyer, ${ }^{35}$ that in the Duisburg'sche Nachlass the Analogies of experience, then called the "analogies of appearance," were at the center of Kant's early efforts to establish the conditions of the possibility of experience, whereas the mathematical principles seem to have been added only to the later versions of the table of the Analytic in view of the publication of the Critique. Now the question is: What is so particular about the dynamical principles that warrants their being reduced to the status of mere contingency?

\section{The contingency of some of the a priori conditions of experience}

We are facing a problem similar to the one we encountered concerning the concept of possibility. Like the latter, contingency belongs to the categories of modality, here as the counterpart of the concept of necessity. Yet the nominal definition of contingency does not reveal 
much, and so beyond the 'logical' meaning of the word we have to search for some 'real' meaning. The logical definition of contingency simply refers to something whose non-being does not imply contradiction. ${ }^{36}$ For a more telling definition, for 'real' definition, we must turn to the way Kant applies it within experience. The details of this use are spelled out in the General Note on the System of the Principles added to the second edition of the Critique. ${ }^{37}$ There we learn that contingency as a category of modality can only be understood if it is linked with another set of categories, namely the categories of relation. Indeed, contingency is for human knowledge essentially a 'relational' concept. It must be related to something else because otherwise we would be left with an "absolute contingency," which according to Kant is too "big" a concept for us. ${ }^{38}$ This coincides with our earlier findings about the absolute possibility: it is the "most" that can be said on the possibility of a concept and as such a finite mind cannot understand what it means. Let us recall that Kant refrains from deciding if, for example, substance in experience is in itself contingent or necessary - we simply cannot know since such a knowledge would call for a speculative use of reason. ${ }^{39}$ Contingency then applies only to the accidents of appearances, since they can be interrelated. Kant gives the case of a body that was first in movement and has come to rest. As such, the mere change from movement to rest proves neither the contingency of this resting state nor of the movement observed earlier: these contrary states of the body occur at different times. To claim that the initial movement is contingent, we have to admit that at that initial time the body could just as well have been at rest. Yet this can only be made comprehensible to our finite knowledge if we presuppose that the reason why the body was in motion, rather than at rest, is that this motion results from some cause. And this is what Kant has in mind when he claims that contingency is comprehensible solely with the help of the categories of relation, in particular cause-and-effect: the movement of the body is a contingent state because, without the action of a cause, the body would have initially been at rest. Contingency is intrinsically linked with the concept of cause. ${ }^{40}$

Can we now apply this reading, valid within the field of experience, to our prior question about the contingency of the transcendental principles that Kant calls dynamical? To be sure, the relation to be established here cannot be to a physical 'cause' as in the example above. But it should at least take the form of a "condition," to use a more neutral term. If the Analogies of Experience are contingent in their application, this means that, as a priori conditions of experience, they are themselves 'conditioned' ${ }^{41}$ And this is exactly what Kant claims in the 
passage where he declares these principles to be contingent: "...the principles of the dynamical use, to be sure, also carry with them the character of an a priori necessity, but only under the condition of empirical thinking in an experience, thus only mediately and indirectly." "While the mathematical principles could precede the material conditions of experience, pertaining as they do only to the form of intuition or to the intensive magnitude of its matter, the dynamical principles on the other hand are in an essential manner related to the "empirical" conditions. This holds for the Analogies as well as for the Postulates of 'Empirical' Thinking. They are conditioned by perception, because they are tied to the givenness of the object. This was already clear in the sentence quoted above on the contingency of these principles: they deal with the "existence of the objects of a possible empirical intuition." Intuition here is not formal but clearly "empirical." This empirical conditioning does not have to be actual though; it merely has to be "possible."

The following conclusion can be drawn from the contingent character of the dynamical principles: among the a priori conditions of the possibility of experience there are some, indeed the most important ones, that are themselves conditioned. And this result does indeed conform with the 'real' meaning of contingency according to Kant: "All contingency is only possible in a conditioned manner." the Critique is not absolute, but relative. Being contingent in their application, the dynamic principles are dependent upon something else: the material (empirical) conditions.

Naturally both the formal and the material conditions are combined for the production of experience, but it is important to specify the terms of this joint contribution. In his lectures on metaphysics, Kant deals repeatedly with the question of multiple causes contributing to a single effect (in our case: experience). He calls them concaussae (or Mitursachen) and suggests that there are two ways for them to bring about their effect: Either they run parallel and remain merely coordinated, or they are subordinated. ${ }^{44}$ If we apply this model to the transcendental production of experience, we are compelled to conclude, after what we have seen, that the dynamical principles are subordinated to the possibility of the material conditions, at least if they are to be $a$ priori cognitions at all. These a priori synthetic propositions are conditioned cognitions, which can in no way lay claim to the status of the unconditioned and which therefore do not have to be implemented by an absolute subject. 
What is said - and what can be said - of the transcendental subject is restricted to its role in the constitution of experience. The spontaneity of the understanding, which culminates in the unity of apperception, is known only through the way it "affects" inner sense. In this case inner sense contains the reflection of this activity, which consists essentially in combining representations. ${ }^{45}$ The empirical representations are at first present in their merely subjective order, and the role of the understanding through its spontaneity is to introduce an objective order among them. For example, if the perception of the warm stone comes first and then afterward the perception of the rays of the sun, it would be erroneous to claim, in accordance with the subjective temporal succession, that the first perception is the cause of the second and to say that the warm stone has produced the hot sunrays. The understanding simply restores the objective order of things.

But the thinking subject thereby runs up against the limits of its spontaneity. Such an activity is limited to the combination of the representations in inner sense. The spontaneity of the understanding does not however produce the manifold of these representations, since it would then be an intuitive understanding. If Kant's transcendental investigation aims at establishing the limits of human knowledge, these limits must also be recognized within the transcendental apparatus: "That understanding through whose self-consciousness the manifold of intuition would at the same time be given, an understanding through whose representation the objects... would at the same time exist, would not require a special act of the synthesis of the manifold for the unity of consciousness, which the human understanding, which merely thinks, but does not intuit, does require. ${ }^{, 46}$ In other words, an understanding that would directly intuit the existence of its object would not be conditioned. It would be totally independent and self-sufficient. It would produce its object of knowledge without any further condition, that is, without external conditions.

We have seen that the material conditions are precisely what show the limits of the $a$ priori conditions of experience. If, on the one hand, inner sense can be affected 'from within' by the spontaneity of the understanding, it can also be affected 'from without', via outer sense, by perception, which represents a radical type of otherness vis-à-vis the transcendental subject. ${ }^{47}$ Kant sometimes calls it the "transcendental object," but it is best known as the notorious "thing in itself." This is the sphere where the passivity of the subject begins, where receptivity takes on its full significance. 
I know all too well that the thing in itself is a hotly disputed topic, but I simply want to stress that Kant's positing of the thing in itself does not represent a leap into the unconditioned. On the contrary, the thing in itself is the ultimate recognition of the conditioned character of the knowing subject and of her knowledge. This second kind of affection of inner sense (via outer sense) cannot be attributed merely to the appearances, nor can it be regarded as a mere epistemic requirement, that is, an object of thought. It is an ontological statement that is constitutive of Kant's investigation of the limits of human knowledge. As Karl Ameriks has argued, there has to be a legitimate place for "transcendental affection" in Kant. ${ }^{48}$ For instance, Kant is aware that the "I think" of the transcendental deduction contains an existential statement although he refrains from exploiting it in a Cartesian fashion and cautions that nothing can be known about the nature of the transcendental subject. The Dialectic will remind us that it is even impossible to say that it is a substance ${ }^{49}$ It is nevertheless admitted as existing. Now it should be possible to say the same of the counterpart of the transcendental subject: the thing in itself. Nothing can be known of its nature, but its specific kind of affection of sensibility is nonetheless essential for the general possibility of experience. ${ }^{50}$

\section{Conclusion}

We raised the question of whether it was legitimate for Kant's transcendental discourse to use certain modal categories beyond the realm of empirical knowledge (experience), that is, outside of the only type of knowledge in which a priori synthetic propositions have access to intuition, formal as well as material. To this question we might answer that the modal categories in Kant's transcendental discourse are ultimately focused on experience itself as a whole. In my view, this reference to possible empirical knowledge is precisely what justifies the use of these modal categories and what confers upon them a claim to truth in Kant's transcendental discourse, although, to be sure, this claim to objective reality is indirect. We are far from the typically "transcendental" use of the categories in the Dialectic. After all, experience in not an absolute possibility, much less an unconditioned necessity, like the dialectical idea of God, for example. We are rather led to conclude with Kant that possible experience is in the end something "entirely contingent, ${ }^{, 51}$ since it depends on a broad set of conditions. And we furthermore discovered that the most important among these transcendental conditions are themselves contingent in turn. Unlike freedom, say, which is construed in the thesis of the third Antinomy as an absolute 
causality, they are not unconditioned conditions. Finally, the focal point of the transcendental conceptual conditions, the 'I think', is not declared in the Analytic to be a noumenal substance, which is what the dialectical reasoning in the Paralogism of Pure Reason tries to establish. On the contrary, the 'I think' is mobilized solely for its contribution to making experience possible.

${ }^{1}$ Letter to M. Herz, AK X, 131 (the abbreviation "AK" refers to the Academy Edition of Kant's writings). Kant focuses his question here on the "intellectual representations."

${ }^{2} \mathrm{KrV}$, B 289, B 219 and B 165-66.

${ }^{3}$ A. G. Baumgarten, Metaphysica $\left({ }^{4} 1757\right), \S 15$, reproduced in AK XVII: 29.

${ }^{4}$ Kant, Vorlesungen über Metaphysik (Volckmann), 1784-85, AK XXVIII: 406. KrV, A 32426/B 380-82; A 232/B 284.

${ }^{5} \mathrm{KrV}$, A 324-26/B 381-82. In Reflexion 4297, Kant even goes so far as to claim that "Was in aller Absicht möglich ist, ist wirklich," AK XVII : 499. See on this topic Burkhard Hafemann, "Logisches Quadrat und Modalbegriffe bei Kant", Kant-Studien, 93 (2011), 415.

${ }^{6} \mathrm{KrV}, \mathrm{A} 232 / \mathrm{B} 285$.

${ }^{7} \mathrm{KrV}$, A 613/B 641 ; trans. P. Guyer and A. Wood in the Cambridge Edition, 574. See Toni Kannisto, "Modality and Metaphysics in Kant", in ed. S. Bacin et al. (ed.), Kant und die Philosophie in weltbürgerlicher Absicht, Book 2 (Berlin/Boston : de Gruyter, 2013), 639.

${ }^{8} \mathrm{KrV}$, A 228/B 280; Reflexion 4005, AK XVII : 382.

${ }^{9} \mathrm{KrV}$, A 326/B 382; trans., 401. "Die hypothetische Möglichkeit [ist], als eine kleinere Möglichkeit zu betrachten, weil sie immer nur unter Restriktion statt findet." Kant, Vorlesungen über Metaphysik (v. Schön), 1780 ?, AK XXVIII : 488.

${ }^{10} \mathrm{Kr} V$, A 222-23/B 269-70.

${ }^{11} \mathrm{KrV}$, A 158/B 197; trans., 283, my emphasis. As their titles indicate, the following studies deal with the same topic as the present paper, but they do not adopt the approach proposed here: A. R. Raggio, "Was heisst 'Bedingungen der Möglichkeit' ?," Kant-Studien, 60 (1969), 153-65 ; Peter Struck, "Kants Formel von den Bedingungen der Möglichkeit von... und die Ableitung der transzendentalen Einheit des Selbstbewusstseins," Prima Philosophia, 6 (1993), 257-66; Arthur Collins, Possible Experience. Understanding Kant's Critique of Pure Reason (Berkeley, Los Angeles and London : University of California Press, 1999). However, in the collection of essays edited by E. Schaper and W. Vossenkuhl under the title Bedingungen der Möglichkeit, 'Transcendental arguments' und transzendentales Denken (Stuttgart : Klett-Cotta, 1984), there is an interesting contribution of Rüdiger Bubner on the self-referentiality of Kant's transcendental argumentation : "Selbstbezüglickeit als Struktur transzendentaler Argumente," 63-79. This is in effect the perspective that I adopt here, although I do not develop it in the same way as Bubner does; he applies it to the different levels of 'synthesis' in Kant's transcendental deduction. For my part, I see self-referentiality in Kant's applying mutatis mutandis the restrictions on the use of the categories in experience to his own transcendental argumentation. In any event, the general conception of self-referentiality laid out by Bubner in an earlier version of his thesis remains valid for my own undertaking: "Transzendental dürfen Kant zufolge nur Erkenntnisse heissen, in denen die Erkenntnis in bezug auf ihre spezifischen Möglichkeiten Thema ist. Wenn dies gilt, so 
thematisiert die transzendental genannte Erkenntnis mit den allgemeinen Erkenntnisbedingungen auch die Voraussetzungen ihres eigenen Entstehens und Arbeitens. Für das transzendentale Argument ist die Selbstbezüglichkeit kennzeichnend... Wenn sich zeigt, dass das Räsonnement über faktische Erkenntnisformen und die Aufklärung von deren Voraussetzungen ohne Benutzung gewisser Elemente jener Erkenntnisformen unmöglich ist, so wird nicht bloss auf der Ebene der Faktizität von Erkenntnis ein faktischer Umstand demonstriert, sondern auf einer Metaebene die ungebrochene Geltung allgemeiner Formen des Erkennens bestätigt." See his "Zur Struktur eines transzendentalen Arguments," in G. Funke (ed.), Akten des 4. Internationalen Kant-Kongresses, Part I (Berlin and New York : De Gruyter, 1974), 23, 25.

I have published on this subject "Self-referentiality in Kant's Transcendental Philosophy," in H. Robinson (ed.), Proceedings of the 8th International Kant Congress, Book II.1 (Milwaukee : Marquette University Press, 1995), 259-67, and "La dimension autoréférentielle du discours sur les 'conditions de possibilité'," in J.-M. Vaysse (ed.), Kant (Paris : Éd. du Cerf, 2008), 191-211.

${ }^{12} \mathrm{KrV}$, B 25; trans. (modified), 149. See Tinca Prunea-Bretonnet, "De l'ontologie à la philosophie transcendantale : dans quelle mesure Kant est-il wolffien ?," in S. Grapotte and T. Prunea-Bretonnet (eds), Kant et Wolff. Héritages et ruptures (Paris : Vrin, 2011), 160.

${ }^{13}$ AK IV: 470.

${ }^{14}$ See Prolegomena, AK IV: 373 ; trans. L. W. Beck in F. E. Baird and W. Kaufmann (eds), Philosophic Classics, Volume III : Modern Philosophy (Upper Saddle River : Prentice Hall, ${ }^{2}$ 1997), 581, my emphasis : “...the word "transcendental”... does not signify something passing beyond all experience but something that indeed precedes it a priori, but that is intended simply to make knowledge of experience possible."

${ }^{15} \mathrm{KrV}$, A 96; trans., 227.

${ }^{16} \mathrm{Kr} V$, A 58/B 82.

${ }^{17} \mathrm{KrV}$, A 146/B 185; trans., 276, my emphasis.

${ }^{18} \mathrm{KrV}$, A 221-22/B 269; trans., 323-24.

${ }^{19} \mathrm{KrV}$, A $157 / \mathrm{B} 196$.

${ }^{20}$ See Prolegomena, AK IV: 274 ; trans., 526 : "In the Critique of Pure Reason I have treated this question synthetically, by making inquiries into pure reason itself and endeavoring in this source to determine the elements as well as the laws of its pure use according to principles. The task is difficult and requires a resolute reader to penetrate by degrees into a system based on no data except reason itself, and which therefore seeks, without resting upon any fact, to unfold knowledge from ist original germs." On this topic see also Manfred Baum, "Die Möglichkeit der Erfahrung und die analytische Methode bei Reinhold," in M. Bondeli and A. Lazzari (eds), Philosophie ohne Beynamen (Basel: Schwabe, 2004), 104-18.

${ }^{21} \mathrm{KrV}, \mathrm{A} 737 / \mathrm{B} 765$.

${ }^{22} \mathrm{KrV}, \mathrm{A} 218 / \mathrm{B} 265-66$.

${ }^{23} \mathrm{KrV}$, A 225/B 273; trans., 325.

${ }^{24}$ According to Giuseppe Motta, the Postulate of necessity has priority over the two others. See his "Qu'est-ce qu'un postulat ? Considérations sur l'anti-constructivisme de Kant," in S.

Grapotte, M. Lequan and M. Ruffing (eds), Kant et la science. La théorie critique et transcendantale de la connaissance (Paris: Vrin, 2011), 142-43.

${ }^{25} \mathrm{KrV}$, A 220/B 267.

${ }^{26} \mathrm{KrV}$, A 111; trans, 234 : "The a priori conditions of a possible experience in general are at the same time conditions of the possibility of the objects of experience." 
${ }^{27} \mathrm{KrV}$, A 92-93/B 125-26; trans., 224, my emphasis: "[T] here are two conditions under which alone the cognition of an object is possible; first, intuition, through which it is given, but only as appearance; second, concept, through which an object is thought that corresponds to this intuition... All appearances therefore necessarily agree with this formal condition of sensibility... the objective validity of the categories, as a priori concepts, rest on the fact that through them alone is experience possible (as far as the form of thinking is concerned)."

${ }^{28} \mathrm{KrV}$, B 203, see also A $165-66$.

${ }^{29} \mathrm{KrV}$, A 178-79/B 221; trans., 297 : "I would be able to compose and determine a priori, i.e., construct the degree of the sensation of sunlight out of about 200,000 illuminations from the moon. Thus we can call the former principles constitutive."

${ }^{30} \mathrm{KrV}, \mathrm{A} 160 / \mathrm{B} 199$.

${ }^{31} \mathrm{KrV}$, A 160-61/B 199-200. In their own specific way, all the principles of Kant's table "anticipate" experience. See for example $K r V$, A 246/B 303, A 762/B 790.

${ }^{32} \mathrm{KrV}$, A 179-80/B 222-23,

${ }^{33}$ I have argued elsewhere that in the Analogies of Experience the point of reference, that is, the tertium comparationis in such an analogy, is pure time. In the principle of causality, for example, the necessary succession between the cause and the effect is analogous to the passage of a pure moment of time $T_{1}$ to the moment $T_{2}$. These two successive moments of time can therefore be considered as the two first terms of the analogy. See my "Qu'est-ce qu'une "analogie" de l'expérience ?," in G. Lafrance, F. Duchesneau and C. Piché (eds), Kant actuel. Hommage à Pierre Laberge (Montreal and Paris : Bellarmin/Vrin, 2000), 217-32. For a similar reading of the paradigmatic function of the order of time in the second Analogy, see Manfred Baum, "Transcendental Proofs in the Critique of Pure reason," in P. Bieri, R.-P. Hortsmann and L. Krüger (eds), Transcendental Arguments and Science (Dordrecht/Boston/London: Reidel, 1979, 16-17.

${ }^{34} \mathrm{KrV}$, A 160/B 199; trans., 284, my emphasis.

${ }^{35}$ Paul Guyer, Kant and the Claims of Knowledge (Cambridge etc.: Cambridge University Press, 1987), 27, 33, 35, 41-2.

${ }^{36} \mathrm{KrV}$, В 290, А 459/B 487.

${ }^{37} \mathrm{KrV}$, В $288-91$.

${ }^{38}$ Kant, Vorlesungen über Metaphysik (v. Schön), AK XXVIII: 499. See also Kant, Preisschrift über die Fortschritte der Metaphysik, AK XX : 329-30

${ }^{39} \mathrm{KrV}$, A 635/B 663; A 227/B 279.

${ }^{40} \mathrm{KrV}$, B 289-90; trans., 335, my emphasis : "That the proposition "Everything contingent must have a cause" may be evident to everyone from mere concepts is not to be denied; but then the concept of the contingent is already taken is such a way that it contains, not the category of modality (as something, the non-existence of which can be thought), but that of relation (as something that can only exist as the consequence of something else), and then it is, of course, an identical proposition : "What can only exist as a consequence has its cause"." See also Giuseppe Motta, Die Postulate des empirischen Denkens überhaupt (Berlin and Boston: de Gruyter, 2012), 62.

${ }^{41}$ If the General Note on the System of Principles establishes that we cannot understand contingency except when the contingent event is to be explained through a 'cause' that precedes it in time, then Kant cannot have recourse to the schematized category of causality in his philosophical investigation, which describes the conditions of experience from without. 
Nevertheless, the restriction imposed upon contingency is maintained insofar as reference is still made to a 'condition' (even if it is not a cause in time).

${ }^{42} \mathrm{KrV}$, A 160/B 199-200; trans., 284, my emphasis.

${ }^{43}$ Kant, Vorlesungen über Metaphysik (Dohna), 1792-93, AK XXVIII: 647.

${ }^{44}$ Kant, Vorlesungen über Metaphysik (Mrongovius), 1782-83, AK XXIX: 844 : "Viele Ursachen, sofern sie zu einem caussato gehören, heissen concaussae, die sind entweder sibi subordinatae, wenn eine vermittelst der andern caussa caussati ist - oder coordinatae, wenn keine als caussa remota, sondern alle als immediate anzusehen sind." Karl Ameriks has drawn the attention to these multiple causes. See his Interpreting Kant's Critiques (Oxford: The Clarendon Press, 2003), 155 n. 42.

${ }^{45} \mathrm{KrV}$, B 156-57 n.; trans., 259: "I do not see how one can find so many difficulties in the fact that inner sense is affected by ourselves... In such acts the understanding always determines the inner sense, in accordance with the combination that he thinks, to the inner intuition that corresponds to the manifold in the synthesis of the understanding."

${ }^{46} \mathrm{KrV}$, B 138-39; trans., 250, my emphasis. See also B 135.

${ }^{47} \mathrm{KrV}, \mathrm{B} 156$.

${ }^{48}$ See Karl Ameriks, Interpreting Kant's Critiques, 157. See also Nicholas Stang, "Did Kant Conflate the Necessary and the A Priori?," Nous, 45 (2011), 467 n. 16. In this note Stang explains that there are so many passages in Kant refering to the affection by the thing in itself that it would be disingenuous to deny them.

${ }^{49} \mathrm{KrV}$, B 422. On Kant's recourse to the term "das Substantiale" in order to explain the dialectic production of the 'fiction' of a transcendent spiritual substance, see my "Die Entstehung der Illusion in den Paralogismen," in. B. Dörflinger and G. Kruck (eds), Über den Nutzen von Illusionen. Die regulativen Ideen in Kant's theoretischer Philosophie (Hildesheim: Olms, 2011), 47-58.

${ }^{50}$ Here arises a similar problem to the one we encountered in the case of contingency. Kant frequently uses the word 'ground' (Grund) in order to explain the affection stemming from the thing in itself. But sometimes he uses the word 'cause' (Ursache), as Aenesidemus-Schulze noted. It goes without saying that this dynamical category is not schematized here and thus does not apply to an appearance within experience. It is instead used to articulate the conditions of possible experience as a whole. But, as opposed to the dialectical use of the category, it still respects the constraints stated in this principle: at first only the effect is known and the principle simply stipulates that there must be some cause or other, which is at that stage totally "indeterminate" ( $K r V$, A 179/B 222; A 199/B 244). The only thing that is certain, according to the principle of causality, is the cause's existence, since the principle cannot anticipate anything of its essence. Yet the unschematized category of causality used by Kant for the thing in itself clearly complies with the indeterminateness mentioned in the principle. And again, its ultimate justification is the possibility of experience, which by definition relates such a cause to the possibility of an "empirical intuition." See my "Kant and the Problem of Affection," Symposium. The Canadian Journal of Continental Philosophy, 8 (2004), 275-97.

${ }^{51} \mathrm{KrV}$, A 737/B765; trans., 642. 